Canadian

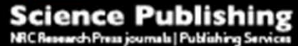

Canadian Journal of Earth Sciences Revue canadienne des sciences de la Terre

\title{
A new hesperornithiform (Aves) specimen from the Late Cretaceous Canadian High Arctic with comments on high latitude hesperornithiform diet
}

\begin{tabular}{|r|l|}
\hline Journal: & Canadian Journal of Earth Sciences \\
\hline Manuscript ID & cjes-2016-0053.R1 \\
\hline Danuscript Type: & Article \\
\hline Complete List of Authors: & $\begin{array}{l}\text { Wilson, Laura; Fort Hays State University, Sternberg Museum of Natural } \\
\text { History and Department of Geosciences; University of Colorado Boulder, } \\
\text { Geological Sciences } \\
\text { Chin, Karen; University of Colorado, Geological Sciences and Museum of } \\
\text { Natural History } \\
\text { Cumbaa, Stephen; Canadian Museum of Nature }\end{array}$ \\
\hline Keyword: & \begin{tabular}{l} 
Hesperornithiform, Paleoecology, High Latitude, Trophic Ecology \\
\hline
\end{tabular} \\
\hline
\end{tabular}

SCHOLARONE

Manuscripts 
A new hesperornithiform (Aves) specimen from the Late Cretaceous Canadian High Arctic with comments on high latitude hesperornithiform diet

Laura E. Wilson

Sternberg Museum of Natural History, Fort Hays State University, Hays, Kansas 67601 U.S.A., lewilson6@fhsu.edu

Department of Geological Sciences, University of Colorado, Boulder, Colorado 80309, U.S.A.

Karen Chin

Department of Geological Sciences and Museum of Natural History, University of Colorado, Boulder, Colorado 80309, U.S.A., Karen.Chin@colorado.edu

Stephen L. Cumbaa

Canadian Museum of Nature, Ottawa, Ontario K1P 6P4, Canada, scumbaa@mus-nature.ca

Corresponding Author:

Laura E. Wilson

Sternberg Museum of Natural History

Fort Hays State University

3000 Sternberg Dr.

Hays, KS 67601

Phone: (785) 639-6192

lewilson6@fhsu.edu 


\begin{abstract}
Here we describe a new hesperornithiform specimen from the Upper Cretaceous Kanguk Formation of Devon Island, Nunavut, Canada. This specimen (NUVF 286) is referred to cf. Hesperornis sp. based on size and shape of femora and teeth preserved with other skeletal elements. Previous osteohistologic analyses indicate a sub-adult ontogenetic stage at the time of death. This new cf. Hesperornis specimen includes the first teeth associated with a high-latitude hesperornithiform, allowing for comments on the trophic behavior of these birds.

Paleoecological reconstructions based on current knowledge of polar assemblages and comparisons to modern birds suggest that high-latitude hesperornithiform birds may have had more varied diets than previously assumed.
\end{abstract}

Key Words: Hesperornithiform, Paleoecology, High Latitude, Trophic Ecology 


\section{Introduction}

Hesperornithiform bird fossils have been recovered from Late Cretaceous Western Interior Seaway (WIS) deposits stretching from Arkansas to Ellesmere Island (Fig. 1), and are well-documented members of northern hemisphere Late Cretaceous high latitude ecosystems (Russell 1967, Bryant 1983, Hills et al. 1999, Hou 1999, Wilson et al. 2011). To date, two largebodied taxa have been described from North American Arctic sediments: Hesperornis and Canadaga. Hesperornis has been described from the Northwest Territories (Russell 1967), the North Slope of Alaska (Bryant 1983), and Ellesmere Island (Hills et al. 1999); Canadaga has been described from Bylot Island (Hou 1999) and Devon Island (Wilson et al. 2011). Here, we describe a new occurrence of cf. Hesperornis from the Campanian Kanguk Formation of Devon Island, Nunavut, Canadian High Arctic. This is the second hesperornithiform specimen and second taxon described from Devon Island.

As pursuit-diving seabirds, hesperornithiforms ostensibly filled an important niche in both mid and high latitude Late Cretaceous marine ecosystems. In the Arctic, adult and juvenile specimens are relatively abundant given the overall limited fossil record from such remote environments. Additionally, hesperornithiforms are one of the few vertebrates that increase in relative abundance with latitude (Nicholls and Russell 1990), highlighting their pervasiveness in these high latitude ecosystems. Although the equator-to-pole temperature gradient was lower during the Late Cretaceous (Amiot et al. 2004), mean annual sea surface temperatures, seasonal photoperiod differences, and other expressions of seasonality likely led to differences in ecosystem structure between mid and high latitudes. Despite this, the trophic roles of hesperornithiforms in different environments along the Seaway have not been explored in detail, especially with regard to the faunal record from polar fossil localities. 
Locality and Geologic Setting

A new hesperornithiform specimen (NUVF 286) was collected in 2003 from Late Cretaceous Kanguk Formation sediments of Eidsbotn graben on Devon Island, Nunavut in the Canadian High Arctic. The bones were encased in mostly uncemented fine glauconitic sand. Interpretation of a nearshore environment for the depositional environment of NUVF 286 is supported by the regressional stratigraphic sequence on Devon Island, presence of woody debris (Chin et al. 2008), and characteristic diatom assemblages (Witkowski et al. 2011).

Collections from Eidsbotn graben on Devon Island have revealed a variety of microfossils, invertebrate and vertebrate macrofossils, and coprolites (Fig. 2) (Chin et al. 2008), providing a glimpse of the Late Cretaceous Arctic marine paleoecosystem. Although there appears to be a bias against preservation of calcareous remains in these Arctic sediments, siliceous, phosphatic, and organic fossil remains were recovered (Chin et al. 2008). Microfossil remains are dominated by diatoms (Chin et al. 2008, Witkowski et al. 2011); silicoflagellates (McCartney et al. 2011), radiolarians, and dinoflagellates (Chin et al. 2008) are also present. Macrofossils recovered include hexactinellid sponges (Rigby et al. 2007), lingulid brachiopods, bivalves, decapod crustaceans, cephalopods, cartilaginous fishes (including at least two genera of lamniform sharks and a ratfish), large bony fishes (a sturgeon, ichthyodectids and pachyrhizodontids), smaller bony fish (such as Enchodus Agassiz, 1835), polycotylid and elasmosaurid plesiosaurs, and hesperornithiform birds (see also Chin et al. 2008). Other smaller bony fish remains were recovered from shale deposits 100-200m below the fossil-bearing greensands in which NUVF 286 was found, but none were found in coeval sediments. 


\section{Materials and Methods}

Most of the NUVF 286 fossil material was collected in a $30 \times 20 \times 20 \mathrm{~cm}$ plaster jacket, but some material was collected as float along with all visible vertebrate and invertebrate fossils. A few associated bones below the specimen could not be collected because they were frozen in permafrost. The specimen was prepared by Charles Magovern (Stone Company). NUVF 286 was compared to material described in the literature and with specimens observed during visits to the Yale Peabody Museum (YPM), University of Kansas Museum of Natural History (KUVP), Sternberg Museum of Natural History (FHSM), and Canadian Museum of Nature (CMN) by the primary author. Around $13 \mathrm{~kg}$ of sediments were collected from the general vicinity of the NUVF 286 locality on a previous expedition to Devon Island; these sediments were sieved for recognizable fossil material in the greensands.

A JEOL JSM-6480LV low vacuum scanning electron microscope at the Nanomaterials Characterization Facility at the University of Colorado at Boulder was used to capture images of teeth associated with NUVF 286. A low vacuum SEM was used, so teeth were not coated or otherwise altered for this analysis. Images were compiled using ImageJ software and edited in Adobe Photoshop.

Institutional abbreviations

CMN, Canadian Museum of Nature, Ottawa; FHSM, Fort Hays State University, Sternberg Museum of Natural History, Hays, Kansas; KUVP, University of Kansas, Vertebrate Paleontology, Museum of Natural History, Lawrence, Kansas; NUVF, Nunavut Vertebrate Fossil collection (housed at CMN, Ottawa); PU, Princeton University (now housed at YPM, New Haven, USA); YPM, Yale Peabody Museum, New Haven, Connecticut. 


\title{
Systematic Paleontology
}

\author{
Aves (Linnaeus 1758) \\ Hesperornithiformes (Fürbringer 1888) \\ Hesperornithidae (Marsh 1872b) \\ Hesperornis (Marsh 1872b) \\ cf. Hesperornis sp.
}

(Figs. 3-4; Appendix 1)

Referred material

Associated skeleton includes: left and right femora, four teeth, partial left and right ilia, rib fragments, and assorted bone fragments (NUVF 286) (Figs. 3-4; Appendix 1).

\section{Diagnosis}

NUVF 286 is referred to the genus cf. Hesperornis on the basis of femur morphology as described by Marsh (1880) and Bell and Chiappe (2015a): short, stout femur with a curved shaft that has a C-shaped lateral margin; large, round head with deep pit on articular surface; transversely expanded distal end; large medullary cavity with cortical bone showing osteosclerosis; distinct, rugose ridges on the medial and lateral surfaces for muscle attachments. Other material associated with NUVF 286 is too fragmentary for detailed morphological comparison. 


\section{Deposition and Preservation}

All elements are assumed to be from one skeleton based on the close spatial association of elements and the relative scarcity of other macrofossils in the greensands. Size correlation (particularly the femora) (Table 1), non-duplication of skeletal elements, similar bone preservation, and the lack of remains from other avian organisms also support the interpretation that the remains belonged to one individual. While the fossil material is highly fragmented, no abrasion is apparent. Some microbial invasion is evident within at least some of the bones, and the right femur shows evidence of invertebrate borings (Fig. 3B).

Fragmentation of the skeletal elements may have occurred due to exposure at the sediment-water interface before burial, and more recent permafrost thawing and frost heaving probably caused further fracturing. Microbial invasion and possible evidence of boring suggest that NUVF 286 was either not immediately buried or was only shallowly buried for some period of time. The low clastic input into the depositional system (as indicated by the glaucony), lack of abrasion or significant weathering, and association of skeletal elements of different sizes, shapes, and densities indicate that the skeleton underwent little to no transport before deposition and burial in the glauconitic sands.

\section{Description}

Femora - The femora of NUVF 286 are the most diagnostic bones preserved (Fig. 3). The right femur (Fig. 3A, 3B) is broken into four pieces, with the mid-shaft region, femur head, and inner distal condyle best preserved. Evidence of boring is found on the shaft of the right femur. Although the right femur has portions of periosteal bone missing, pronounced rugosities for 
muscle attachments on the medial surface of the femoral shaft are apparent. The left femur is crushed with most of the posterior portion missing (Fig. 3C, 3D). The left femur head was displaced from the rest of the femur and is cemented to an indurated block of sediment containing pelvic fragments. The greater trochanter and distal medial condyle are missing, but the distal lateral condyle is preserved.

Comparisons of the NUVF 286 femora to Hesperornis regalis Marsh, 1872 femora described by Marsh (1880), and other YPM, KUVP, and FHSM specimens, reveal NUVF 286 to be morphologically comparable to $H$. regalis specimens from Kansas. Observable femoral synapomorphies shared between NUVF 286 and the genus Hesperornis, based on the phylogenetic analysis by Bell and Chiappe (2015a), include: a slightly cranially convex shaft in medial view, and a strong S-shape in the medial margin of the femur shaft. NUVF 286 also has a pocketed patellar sulcus (see Bell and Chiappe 2015b). The size of NUVF 286 and H. regalis specimens are equivalent (Table 1), though a previous histologic description of NUVF 286 (Wilson and Chin 2014) indicates that this specimen was a sub-adult approaching skeletal maturity at the time of death. The only apparent difference between $H$. regalis and the new Arctic specimen is that the fibular articular surface of NUVF 286 is more laterally and less posteriorly inflected than other H. regalis specimens (Marsh 1880, Bell and Chiappe 2015b, Aotsuka and Sato 2016, personal observation); the ridges on the fibular articular surface also are not as pronounced. However, given the fragmentary nature of the elements, the orientations of some features are difficult to accurately reconstruct. Additionally, since this specimen is a subadult, ontogenetic variation cannot be discounted. The NUVF 286 femora are also morphologically similar to specimens informally assigned to H. chowi Martin and Lim, 2002, but 
this taxon was not supported as distinct from $H$. regalis in the most recent phylogenetic analysis (Bell and Chiappe 2015a) and is now listed as Hesperornis sp. on Table 1.

Ilia fragments - The ilia of NUVF 286 are still mostly encased by a cemented glauconitic matrix, which was left intact to support the bones. However the preserved portions of the left and right ilia appear to be articulated. The lateral portion of the left ilium near the acetabula is clearly exposed but is not well preserved (Appendix 1). The head of the left femur was preserved in close association with the left ilium in the region of the acetabulum. No details from these fragments assisted with taxonomic identification.

Teeth-Four teeth were recovered from the plaster jacket along with the cf. Hesperornis bones. Because the teeth were detached from jaw elements, we are unable to determine tooth position within the jaw. Tooth crown length ranges from $5.0 \mathrm{~mm}$ to $6.2 \mathrm{~mm}$, which are comparable in size to teeth from YPM 1206 and KUVP 71012. All teeth are labio-lingually compressed and recurved, which is consistent with descriptions of Hesperornis teeth by Marsh (1880), and other teeth identified as Hesperornis (KUVP 71012) and Parahesperornis (KUVP 2287). The two smaller teeth $\left(\mathrm{T}_{3}\right.$ and $\left.\mathrm{T}_{4}\right)$ are more strongly recurved than the two larger teeth $\left(\mathrm{T}_{1}\right.$ and $\mathrm{T}_{2} ;$ Fig. 4). Carinae are present in some teeth (e.g., $\mathrm{T}_{4}$ ), but are weak or absent in others. No serrations are evident.

The tip of one tooth $\left(\mathrm{T}_{1}\right)$ is broken, but it is unclear whether this reflects post-mortem damage or occurred during prey capture or feeding. No spalling or other macroscopic alteration is evident on the teeth. All teeth show fine wrinkles (crenulations) in the enamel layer, resulting in a rough enamel texture formed by the series of low, irregular ridges that extend longitudinally 
from the tooth apex to gum line (Fig. 4). The density of enamel wrinkles varies among the four teeth. Similar ridges have been reported in Kansas Hesperornis teeth (Sander 1999).

In general, the size and morphology of the teeth associated with the NUVF 286 specimen are consistent with other Hesperornis teeth (Marsh 1880). The NUVF 286 teeth also do not resemble teeth from any other vertebrates recovered from Devon Island. They lack the robust, regular ridges and conical shape of polycotylid plesiosaur teeth. Some unidentified large fish bones were collected nearby, but the NUVF 286 teeth are much smaller than would be expected of teeth associated with those bones, and do not match the teeth of known fish from the region. Ichthyodectid teeth are typically conical and not recurved, pachyrhizodontid teeth are smooth and conical, and Enchodus teeth are either small and smooth, or much larger with regular ridges near the base and a smooth crown. Only Hesperornis bones were recovered at this specific locality and there are no duplicate elements (suggesting only one individual is represented). Moreover, sediment sieving in the area demonstrated that vertebrate remains are rare at this locality. We thus infer that the teeth are associated with the other skeletal elements assigned to NUVF 286, and represent cf. Hesperornis teeth.

Assorted bone fragments - Additional bone fragments identified as ribs (Appendix 1), vertebrae, and a tibiotarsus are also referred to NUVF 286, but are too fragmentary for accurate measurements or to assist with taxonomic identification. A partial internal mold of one tibiotarsus was also preserved.

\section{Discussion}


As noted above, two hesperornithiform genera have been identified from the North American Arctic (Fig. 1): Canadaga and Hesperornis. The new specimen described in this study thus falls within the established biogeographic range for hesperornithiform birds, and specifically the genus Hesperornis. The only Hesperornis taxon identified to species from the Arctic is $H$. regalis (Russell 1967), with others identified to genus only (Bryant 1983, Hills et al. 1999). Recent description of a $H$. cf. rossicus Nessov and Yarkov 1993 specimen from Manitoba suggests a holarctic distribution for the species (Aotsuka and Sato 2016). Undescribed specimens attributed to hesperornithiforms have also been collected from Eglinton Island and Horton River (Northwest Territories), and are housed at the CMN.

Despite the crushed and fragmentary preservation of the femora, several key characters are preserved and support taxonomic identification to the genus Hesperornis. Comparisons with other hesperornithiform femora show that this new Arctic specimen is comparable in size to $H$. regalis specimens from Kansas and Manitoba (Table 1) - even though histology patterns indicate that NUVF 286 was a sub-adult individual approaching skeletal maturity (Wilson and Chin 2014). The femora of NUVF 286 are larger than a large hesperornithiform specimen from Anderson River, Northwest Territories (CMN 10441) assigned to H. regalis by Russell (1967), but the ontogenetic stage of CMN 10441 is unknown. Martin and Lim (2002) suggest that the Anderson River specimens may be assigned to $H$. chowi based on large size. However, no $H$. chowi femora have been formally described in the literature, and $H$. chowi is not supported in the most recent hesperornithiform phylogenetic analysis, as it does not code differently than $H$. regalis (Bell and Chiappe 2015a). The NUVF 286 femora are also more robust than those of the elongate Baptornis advenus (Martin and Tate, 1976) and Parahesperornis alexi (Martin 1984), and the trochanter ridge of NUVF 286 is laterally expanded away from the shaft (a 
Hesperornithidae character) (Bell and Chiappe 2015a). The pocketed patellar sulcus is observable in NUVF 286, distinguishing it from Baptornis and the new genus Fumicollis (Bell and Chiappe 2015b).

In a previous study, Wilson et al. (2011) described a Canadaga arctica specimen (NUVF 284) from Devon Island, and noted that the large Hesperornis specimen from the Northwest Territories (CMN 10441) might be assigned to C. arctica based on size and proximity to the type locality. Though Hou (1999) referred two fragmentary femora to C. arctica, the only thoroughly described and clearly identified C. arctica material consists of cervical vertebrae (Hou 1999, Wilson et al. 2011). Until additional material is found, assigning Arctic hesperornithiform appendicular skeletal elements to $C$. arctica is tentative at best, especially when this large hesperornithiform resembles other taxa so closely. Accordingly, based on comparisons with femora held in museum collections and described in the literature — and considering the taxonomic issues discussed above-we assign NUVF 286 to cf. Hesperornis sp. We hope that future discoveries of hesperornithiform fossils from the Arctic will shed light on these taxonomic issues, especially regarding the validity of multiple species assigned to Hesperornis (sensu Bell and Chiappe 2015a).

Hesperornithiform Feeding Behavior

Hesperornithiforms are assumed to have been piscivorous based on jaw morphology and the presence of teeth (Green 1962, Martin and Tate 1976, Rees and Lindgren 2005, Martin and Naples 2008). Morphological analysis of the mandibles has indicated that lateral movement was possible at the posterior margin of the mandibular bones to enable swallowing of larger prey items (Martin and Naples 2008). While gape (width of jaws at contact with skull) has been 
shown to be a controlling factor on prey size (e.g. Hulsman 1981, Erikstad 1990), it cannot be used to determine prey type. The only direct evidence suggesting piscivory is a coprolite/intestinal cast containing fish remains associated with a $B$. advenus skeleton from the Niobrara Chalk of Kansas (Martin and Tate 1976). However, the identification of B. advenus as the producer of the coprolite is tenuous, as the association is based solely on proximity to the bird skeleton and the coprolite's lack of a spiral morphology (which is attributable to certain fish taxa).

Despite possible adaptations to piscivory within the clade, there is little evidence that hesperornithiforms were exclusively piscivorous. We propose that these birds exploited more diverse food resources in ancient high latitude ecosystems. Generalized, flexible diets would have offered advantages at high latitudes, regardless of whether hesperornithiforms overwintered in the Arctic or migrated south along the Seaway. Furthermore, as in our present-day interglacial world, Arctic marine ecosystem structure in the greenhouse world of the Campanian appears to have been distinctly different from that of lower latitude ecosystems (Chin et al. 2008). While fossil evidence for the smaller fishes that often characterize seabird diets is abundant in mid latitude Campanian sediments (Nicholls and Russell 1990, Carpenter 2003, 2006, Shimada and Fielitz 2006), studies documenting Late Cretaceous high latitude fossil assemblages (both Arctic and Antarctic) (Kriwet et al. 2006, Martin and Crame 2006, Chin et al. 2008) report a paucity of small- and medium-sized fishes. Chin et al. (2008) reported only one small to medium-sized fish taxon (Enchodus) from the greensands of the Campanian Kanguk Formation on Devon Island, even though all observed macrofossils were collected. Around $13 \mathrm{~kg}$ of glauconitic sediment collected on a previous expedition in the general vicinity of the NUVF 286 locality was sieved for microvertebrate and invertebrate remains, and only a handful of unidentifiable vertebrate and 
invertebrate remains were recovered (Alex Dutchak, personal communication). Similar results of low osteichthyan diversity and abundance, especially teleosts, are reported from Upper Cretaceous sediments of James Ross Basin, Antarctica (Kriwet et al. 2006, Martin and Crame 2006). Kriwet et al. (2006) found fishes at lower levels of the food chain to be lacking in these Antarctic deposits, while larger, top predator fish were significantly more abundant.

Taphonomic bias can offer one explanation for the lack of small- and medium-sized fish in the polar fossil record. Nevertheless, though biostratinomic and diagenetic processes undoubtedly affected fossil preservation in these environments, Martin and Crame (2006) concluded that the low abundance of intermediate and lower trophic level fishes in Late Cretaceous Antarctic deposits represents a genuine absence from the ecosystem rather than a taphonomic bias. Fish bones are fragile, but their teeth are generally more resistant to destructive forces. Given the preservation of diverse fossils recovered from Devon Island (Chin et al. 2008; this study), it seems likely that fish teeth would be more common if small- and mid-sized fish were present in abundances comparable to what has been found at lower latitudes. Seasonal migration of fish populations may also explain the paucity of small to medium-sized fish fossils in the Devon Island assemblage. If some species of fish only seasonally inhabited polar environments, fewer would be preserved, contributing to their poor fossil record.

Despite the Late Cretaceous greenhouse climate (e.g. Barron 1983, Hay et al. 1993, Huber et al. 1995, 2002, Herman and Spicer 1997, Jenkyns et al. 2004, Spicer and Herman 2010, Dennis et al. 2013), organisms at high latitudes were still subject to seasonal changes in photoperiod, temperature, and resource availability. Seasonality likely affected the overall marine trophic structure (Chin et al. 2008) and relative abundance of organisms (Kauffman 1984, Nicholls and Russell 1990), and would have affected hesperornithiform feeding behavior. 
Evidence indicates that at least some Campanian Arctic marine food webs in the Devon Island area were relatively short, with fewer trophic levels between primary producers and large predators (Chin et al. 2008). These Campanian Arctic trophic patterns are similar to those in modern high latitude marine ecosystems, which often have shortened food chains where apex marine predators feed directly on smaller organisms at lower trophic levels (Laws 1985, Sanger 1987, Ainley and DeMaster 1990). In modern polar environments, seabirds (which are generally significantly smaller than Hesperornis and Canadaga) are abundant top predators and feed more often on zooplankton (krill, copepods) and first order carnivores (small fish) than on larger, highorder carnivores (large fish). One benefit of abbreviated food chains is that predators feeding at lower trophic levels are more efficient in utilizing seasonal phytoplankton blooms (Sanger 1987).

Having a more flexible diet would have allowed high latitude hesperornithiforms to adjust to seasonal variations in the availability of different prey species. Diet switching has also been suggested for other toothed Mesozoic (Zhou et al. 2004) and early Cenozoic (Naish 2014) birds. Additionally, the recurved crown, enamel wrinkles, pointed apex, lack of sharp carinae, and absence of serrations in Hesperornis teeth (Fig. 4) best align with descriptions of extinct marine reptile teeth that were likely used for piercing or associated with a generalized diet (Massare 1987).

Consequently, hesperornithiform diets probably displayed seasonal fluctuations as these birds switched feeding on different prey organisms. The remains of benthic invertebrates such as lobsters and nektonic invertebrates like squid were found in the Devon Island deposits (Fig. 2), but most soft-bodied invertebrates typically have a poor fossil record. For example, krill have no fossil record, though molecular analysis indicates that the origin of krill dates back to the Early Cretaceous (Jarman 2001). In general, coleoid cephalopod remains are common in sediments 
from the Western Interior Seaway, and Elzanowski (1983) suggests that squid may have provided a reliable food source for hesperornithiforms.

In modern systems, soft-bodied invertebrates like krill, copepods, and squid play a large role in seabird diets (e.g., Ashmole and Ashmole 1967, Sanger 1987, Kooyman 2002, Bost et al. 2009). In addition, extant seabirds are known to have variable diets as different prey items migrate in and out of their foraging areas (Shealer 2001, Ainley 2002). In the modern Gulf of Alaska, for example, Common Murres and Marbled Murrelets feed on demersal crustaceans during the winter rather than pelagic fish (Sanger 1987). Sanger speculates that pelagic-benthic coupling (exemplified by seabirds feeding on the benthos) provides a more reliable source of food in highly seasonal environments, in which prey species change and/or become scarce between seasons. Additionally, changes in diet within a species across a geographic range have been documented in some seabirds (e.g., Polito et al. 2002), as well as changes in diet correlated with climatic shifts through time (Emslie et al. 1998, Emslie and McDaniel 2002, Polito et al. 2002).

The discovery of the fossil bird specimen NUVF 286 on Devon Island augments our understanding of the known distribution of Hesperornis, and supports the inference that these birds were widespread in the Arctic during the Late Cretaceous. As such, they likely played important roles in ancient polar marine ecosystems through their feeding activities.

Reconstructions of the ancient Devon Island food web and comparisons with modern seabird communities offer complementary perspectives on Arctic hesperornithiform diets. The paucity of mid-sized and smaller fossil fish in Arctic sediments does not seem to support the commonly held idea that Arctic hesperornithiforms were primarily piscivorous. This fossil evidence plus studies of extant seabird diets suggest that high latitude hesperornithiform populations had more 
varied and seasonally influenced diets than previously hypothesized. Although small- and medium-sized fish may have comprised a portion of their diet, utilization of other organismssuch as crustaceans and cephalopods - may have helped buffer resident or migratory hesperornithiforms from seasonal fluctuations in prey availability.

\section{Acknowledgments}

The authors thank J. Kotierk, J. Ross, and D. Stenton of the Nunavut Government Department of Culture, Language, Elders and Youth for access to NUVF 286. R. Geiss of the Nanomaterials Characterization Facility, University of Colorado Boulder assisted with SEM use and photography. J. Bloch, J. Eberle, and J. Storer helped collect fossils and sediments mentioned in this paper. C. Magovern prepared NUVF 286. T. Sato assisted in identifying plesiosaur material and A. Dutchak and D. Patten helped sort bulk sediment. D. Burnham (University of Kansas Museum of Natural History) provided images and measurements of KUVP teeth for comparison. J. Eberle, T. Marchitto, A. Cruz, H. Larsson, and two anonymous reviewers provided helpful feedback on early drafts of this manuscript. NUVF 286 was collected under NSF Polar Programs Award no. 0241002 to K. Chin; a Shell Oil Grant to L. Wilson from the Department of Geological Science at University of Colorado, Boulder provided funding for SEM use. Funds from the late Margaret and Hayes Caldwell help maintain the Chin laboratory.

\section{References}

Agassiz, L. 1833-1843 (1833, 1835, 1843). Recherches sur les poissons fossiles (5 volumes). Neuchâtel, Imprimerie de Patitpierre, 1420 p.

Ainley, D.G. 2002. The Adelie Penguin: Bellwether of Climate Change. Columbia University Press, New York. 
Ainley, D.G., and DeMaster, D.P. 1990. The upper trophic levels in polar marine ecosystems. In Polar Oceanography: Part B: Chemistry, Biology, and Geology. Edited by J. Walker O. Smith. Academic Press, Inc. pp. 599-630.

Amiot, R., Lécuyer, C., Guffetaut, E., Fluteau, F., Legendre, S., and Martineau, F. 2004. Latitudinal temperature gradient during the Cretaceous Upper Campanian-Middle Maastrichtian: $\delta 180$ record of continental vertebrates. Earth and Planetary Science Letters 226: 225-272.

Aotsuka, K., and Sato, T. 2016. Hesperornithiformes (Aves: Ornithurae) from the Upper Cretaceous Pierre Shale, Southern Manitoba, Canada. Cretaceous Research 63: 154-169. doi:10.1016/j.cretres.2016.03.003.

Ashmole, N.P., and Ashmole, M.J. 1967. Comparative feeding ecology of sea birds of a tropical oceanic island. Bulletin of the Peabody Museum of Natural History 24: 1-131.

Bardack, D. 1968. Fossil vertebrates from the marine Cretaceous of Manitoba. Canadian Journal of Earth Sciences 5: 145-153.

Barron, E.J. 1983. A warm, equable Cretaceous: The nature of the problems. Earth-Science Reviews 19: 305-338.

Bell, A., and Chiappe, L.M. 2015a. A species-level phylogeny of the Cretaceous Hesperornithiformes (Aves: Ornithuromorpha): Implications for body size evolution amongst the earliest diving birds. Journal of Systematic Palaeontology 14(3): 239-251. doi:10.1080/14772019.2015.1036141.

Bell, A., and Chiappe, L.M. 2015b. Identification of a new hesperornithiform from the Cretaceous Niobrara Chalk and implications for ecologic diversity among early diving birds. PLoS One 10(11). doi:10.1371/journal.pone.0141690.

Bost, C.A., Cotte, C., Bailleul, F., Cherel, Y., Charrassin, J.B., Guinet, C., Ainley, D.G., and Weimerskirch, H. 2009. The importance of oceanographic fronts to marine birds and mammals of the southern oceans. Journal of Marine Systems 78: 363-376.

Bryant, L.J. 1983. Hesperornis in Alaska. PaleoBios 40: 1-8.

Carpenter, K. 2003. Vertebrate biostratigraphy of the Smoky Hill Chalk (Niobrara Formation) and the Sharon Springs Member (Pierre Shale). In Approaches in High-Resolution Stratigraphic Paleontology. Edited by P.J. Harries. Kluwer Academic Publishers, Amsterdam. pp. 421-437.

Carpenter, K. 2006. Comparative vertebrate taphonomy of the Pembina and Sharon Springs Members (Middle Campanian) of the Pierre Shale, Western Interior. Paludicola 5(4): 125-149.

Chin, K., Bloch, J., Sweet, A., Tweet, J., Eberle, J., Cumbaa, S., Witkowski, J., and Harwood, D. 2008. Life in a temperate Polar sea: A unique taphonomic window on the structure of a Late Cretaceous Arctic marine ecosystem. Proceedings of the Royal Society B 275(1652): 2675-2685.

Davis, L.C., and Harris, K. 1997. Discovery of fossil Cretaceous bird in Southwest Arkansas. Journal of the Arkansas Academy of Science 51: 197-198.

Dennis, K.J., Cochran, J.K., Landman, N.H., and Schrag, D.P. 2013. The climate of the Late Cretaceous: New insights from the application of the carbonate clumped isotope thermometer to Western Interior Seaway macrofossil. Earth and Planetary Science Letters 362: 51-65. doi:10.1016/j.eps1.2012.11.036.

Elzanowski, A. 1983. Birds in Cretaceous ecosystems. Acta Palaeontologica Polonica 28(1-2): 75-93. 
Emslie, S.D., Fraser, W., Smith, R.C., and Walker, W. 1998. Abandoned penguin colonies and environmental change in the Palmer Station area, Anvers Island, Antarctic Peninsula. Antarctic Science 10(3): 257-268.

Emslie, S.D., and McDaniel, J.D. 2002. Adelie penguin diet and climate change during the middle to late Holocene in northern Marguerite Bay, Antarctic Peninsula. Polar Biology 25: 22-29.

Erikstad, K.E. 1990. Winter diets of four seabird species in the Barents Sea after a crash in the capelin stock. Polar Biol 10(8): 619-627. doi:10.1007/BF00239373.

Fox, R.C. 1974. A Middle Campanian, nonmarine occurrence of the Cretaceous toothed bird Hesperornis Marsh. Canadian Journal of Earth Sciences 11: 1335-1338.

Fürbringer, M. 1888. Untersuchungen zur Morphologie und Systematik der Vögel, zugleich ein Beitrag zur Anatomie der Stützund Bewegungsorgane. van Hokema, Amsterdam.

Green, M. 1962. South Dakota birds with teeth. South Dakota Bird Notes 14: 14-16.

Hay, W.W., Eicher, D.L., and Diner, R. 1993. Physical oceanography and water masses in the Cretaceous Western Interior Seaway. In Evolution of the Western Interior Basin. Edited by W.G.E. Caldwell and E.G. Kauffman. Geological Association of Canada Special Paper 39. pp. 297-318.

Herman, A.B., and Spicer, R.A. 1997. New quantitative palaeoclimate data for the Late Cretaceous Arctic: evidence for a warm polar ocean. Palaeogeography, Palaeoclimatology, Palaeoecology 128: 227-251.

Hills, L.V., Micholls, E.L., Nunez-Betelu, L.M., and McIntyre, D.J. 1999. Hesperornis (Aves) from Ellesmere Island and palynological correlation of known Canadian localities. Canadian Journal of Earth Sciences 36: 1583-1588.

Hou, L.-H. 1999. New hesperornithid (Aves) from the Canadian Arctic. Vertebrata PalAsiatica 37(3): 228-233.

Huber, B.T., Hodell, D.A., and Hamilton, C.P. 1995. Middle-Late Cretaceous climate of the southern high latitudes: Stable isotopic evidence for minimal equator-to-pole thermal gradients. GSA Bulletin 107(10): 1164-1191.

Huber, B.T., Norris, R.D., and MacLeod, K.G. 2002. Deep-sea paleotemperature record of extreme warmth during the Cretaceous. Geology 30(2): 123-126.

Hulsman, K. 1981. Width of gape aa a determinant of size of prey eaten by terns. EMU 81(1): 29-32.

Jarman, S.N. 2001. The evolutionary history of krill inferred from nuclear large subunit rDNA sequence analysis. Biological Journal of the Linnean Society 73(2): 199-212. doi:10.1111/j.1095-8312.2001.tb01357.x.

Jenkyns, H.C., Forster, A., Schouten, S., and Damste, J.S.S. 2004. High temperatures in the Late Cretaceous Arctic Ocean. Nature 432: 888-892.

Kauffman, E.G. 1984. Paleobiogeography and evolutionary response dynamic in the Cretaceous Western Interior Seaway of North America. In Jurassic-Cretaceous Biochronology and Paleogeography of North America. Edited by G.E.G. Westermann. Geological Association of Canada Special Paper 27. pp. 273-306.

Kooyman, G.L. 2002. Evolutionary and ecological aspects of some Antarctic and sub-Antarctic penguin distributions. Oecologia 130: 485-495.

Kriwet, J., Lirio, J.M., Nunez, J.K., Puceat, E., and Lecuyer, C. 2006. Late Cretaceous Antarctic fish diversity. In Cretaceous-Tertiary High-Latitude Palaeoenvironments, James Ross 
Basin, Antarctica. Edited by F.J.E. Pirrie and J.A. Crame. Geological Society, London, Special Publications. pp. 83-100.

Laws, R.M. 1985. The ecology of the Southern Ocean. American Scientist 73: 119-125.

Linnaeus, C. 1758. Systema naturae per regna tria naturae, secundum classes, ordines, genera, species, cum characteribus, differentiis, synonymis, locis. In 10th edition. Holmiae Salvii.

Marsh, O.C. 1872a. Discovery of a remarkable fossil bird. American Journal of Science 103: 5657.

Marsh, O.C. 1872b. Preliminary description of Hesperornis regalis, with notice of four other new species of Cretaceous birds. American Journal of Science s3-3(17): 360-365. doi:10.2475/ajs.s3-3.17.360.

Marsh, O.C. 1876. Notice of new Odontornithes. American Journal of Science 11(66): 509-511.

Marsh, O.C. 1880. Odontornithes: A monograph of the extinct toothed birds of North America. Report of the United States Geological Exploration of the Fortieth Parallel, Washington, DC.

Marsh, O.C. 1893. A new Cretaceous bird allied to Hesperornis. American Journal of Science 45(265): 81-82.

Martin, J.E., and Crame, J.A. 2006. Palaeobiological significance of high-latitude Late Cretaceous vertebrate fossils from the James Ross Basin, Antarctica. In CretaceousTertiary High-Latitude Palaeoenvironments, James Ross Basin, Antarctica. Edited by F.J.E. Pirrie and J.A. Crame. Geological Society, London Special Publications. pp. 109124.

Martin, J.E., and Varner, D.W. 1992. The occurrence of Hesperornis in the Late Cretaceous Niobrara Formation of South Dakota. Proceedings of the South Dakota Academy of Science 71: 95-97.

Martin, L.D. 1984. A new hesperornithid and the relationship of the Mesozoic birds. Transactions of the Kansas Academy of Science 87(3-4): 141-150.

Martin, L.D., and Lim, J.-D. 2002. New information on the hesperornithiform radiation. In Proceedings of the 5th Symposium of the Society of Avian Paleontology and Evolution. Edited by Z. Zhou and F. Zhang. Beijing. pp. 165-174.

Martin, L.D., and Naples, V.L. 2008. Mandibular kinesis in Hesperornis. Oryctos 7: 61-65.

Martin, L.D., and Tate, J. 1976. The Skeleton of Baptornis advenus (Aves: Hesperonithiformes). Smithsonian Contributions to Paleobiology 27: 35-66.

Massare, J.A. 1987. Tooth morphology and prey preference of Mesozoic marine reptiles. Journal of Vertebrate Paleontology 7(2): 121-137. doi:10.1080/02724634.1987.10011647.

McCartney, K., Witkowski, J., and Harwood, D.M. 2011. Unusual assemblages of Late Cretaceous silicoflagellates from the Canadian Archipelago. Revue de micropalentologie 54: $31-58$.

Naish, D. 2014. The fossil record of bird behaviour. Journal of Zoology 292(4): 268-280. doi:10.1111/jzo.12113.

Nessov, L.A., and Yarkov, A.A. 1993. Hesperornithiforms in Russia. Russian Journal of Ornithology 2: 37-54. [In Russian]

Nicholls, E.L., and Russell, A.P. 1990. Paleobiogeography of the Cretaceous Western Interior Seaway of North America: the vertebrate evidence. Palaeogeography, Palaeoclimatology, Palaeoecology 79: 149-169.

Polito, M., Emslie, S.D., and Walker, W. 2002. A 1000-year record of Adelie penguin diets in the southern Ross Sea. Antarctic Science 14(4): 327-332. 
Rees, J., and Lindgren, J. 2005. Aquatic birds from the Upper Cretaceous (Lower Campanian) of Sweden and the biology and distribution of hesperornithiforms. Palaeontology 48(6): $1321-1329$.

Rigby, J.K., Chin, K., Bloch, J.D., and Tweet, J.S. 2007. A new hexactinellid sponge from the Cretaceous of Devon Island, Canadian High Arctic. Canadian Journal of Earth Sciences 44(9): 1235-1242.

Russell, D.A. 1967. Cretaceous vertebrates from the Anderson River N.W.T. Canadian Journal of Earth Sciences 4: 21-38.

Sander, P.M. 1999. The microstructure of reptilian tooth enamel: Terminology, function, and phylogeny. Munchner Geowissenschaftliche Abhandlungen 38: 1-102.

Sanger, G.A. 1987. Trophic levels and trophic relationships of seabirds in the Gulf of Alaska. In Seabirds: Feeding Ecology and Role in Marine Ecosystems. Edited by J.P. Croxall. Cambridge University Press. pp. 229-257.

Shealer, D.A. 2001. Foraging behavior and food of seabirds. In Biology of marine birds. Edited by E.A. Schrieber and J. Burger. CRC Press. pp. 137-177.

Shimada, K., and Fielitz, C. 2006. Annotated checklist of fossil fishes from the Smoky Hill Chalk of the Niobrara Chalk (Upper Cretaceous) in Kansas. In Late Cretaceous vertebrates from the Western Interior. Edited by S.G. Lucas and R.M. Sullivan. New Mexico Museum of Natural History and Science Bulletin. pp. 193-214.

Shufeldt, R.W. 1915. The fossil remains of a species of Hesperornis found in Montana. The Auk 32(3): 290-294.

Spicer, R.A., and Herman, A.B. 2010. The Late Cretaceous environment of the Arctic: A quantitative reassessment based on plant fossils. Palaeogeography, Palaeoclimatology, Palaeoecology 295(3-4): 423-442. doi:10.1016/j.palaeo.2010.02.025.

Tokaryk, T.T. 1999. A Toothed Bird Hesperornis sp. (Hesperornithiformes) from the Pierre Shale (Late Cretaceous) of Saskatchewan. The Canadian Field-Naturalist 113: 670-672.

Wilson, L.E., and Chin, K. 2014. Comparative osteohistology of Hesperornis with reference to pygoscelid penguins: The effects of climate and behaviour on avian bone microstructure. Royal Society Open Science 1(3): 140245. doi:10.1098/rsos.140245.

Wilson, L.E., Chin, K., Cumbaa, S., and Dyke, G. 2011. A high latitude hesperornithiform (Aves) from Devon Island: Palaeobiogeography and size distribution of North American hesperornithiforms. Journal of Systematic Palaeontology 9(1): 9-23.

Witkowski, J., Harwood, D.M., and Chin, K. 2011. Taxonomic composition, paleoecology and biostratigraphy of Late Cretaceous diatoms from Devon Island, Nunavut, Canadian High Arctic. Cretaceous Research 32: 277-300.

Zhou, Z., Clarke, J., Zhang, F., and Wings, O. 2004. Gastroliths in Yanornis: An indication of the earliest radical diet-switching and gizzard plasticity in the lineage leading to living birds? Naturwissenschaften 91(12): 571-574. doi:10.1007/s00114-004-0567-z. 


\section{Figure captions}

Table 1. Femora measurements of NUVF 286 compared to other Hesperornis femora. All measurements in millimeters $(\mathrm{mm})$.

Fig. 1. Late Cretaceous North American distribution of specimens attributed to the genus Hesperornis. Map CColorado Plateau Geosystems 2013, used with permission. 1, Hesperornis sp., Ozan Formation (Davis and Harris 1997); 2, Hesperornis regalis, Niobrara Formation (Marsh 1872a, 1880); 3, Hesperornis crassipes, Niobrara Formation (Marsh 1876); 4, Hesperornis sp., Pierre Shale (Martin and Tate 1976); 5, Hesperornis chowi, Pierre Shale (Martin and Lim 2002); 6, Hesperornis bairdi, Pierre Shale (Martin and Lim 2002); 7, Hesperornis regalis, Niobrara Formation (Martin and Varner 1992); 8, Hesperornis altus, Judith River Formation/Clagget Formation (Marsh 1893, Shufeldt 1915, but see Wilson et al. 2011 for discussion of taxonomy); 9, Hesperornis mengeli, Pierre Shale (Martin and Lim 2002); 10, Hesperornis sp., Pembina Formation (Nicholls and Russell 1990); 11, Hesperornis regalis, Hesperornis howi, Hesperornis macdonaldi, Hesperornis mengeli, Hesperornis lumgairi, Hesperornis cf. rossicus, Pembina Formation (Bardack 1968; Aotsuka \& Sato 2016); 12, Hesperornis cf. regalis, Foremost Formation (Fox 1974); 13, Hesperornis sp., Pierre Shale (Tokaryk 1999); 14, Hesperornis regalis, Smoking Hills Formation (Russell 1967); 15, Hesperornis sp., Ignek Formation (Bryant 1983); 16, Hesperornis sp., Kanguk Formation (this paper); 17, Hesperornis sp., Kanguk Formation (Hills et al. 1999). 
Fig. 2. Stacked histograms showing relative number of fossils collected at Eidsbotn and Viks Fiord grabens in the Kanguk Formation on Devon Island. Top (darker) bars indicate numbers of taxa found within coprolites. Note that all body fossils were collected, but only a subset of coprolites were collected.

Fig. 3. Photographs and line drawings of identifiable bones attributed to NUVF 286. Right femur in cranial (A) and caudal (B) views; left femur in cranial (C) and caudal (D) views; ilia (E) embedded in glauconite matrix; rib fragments (F). Abbreviations: b, boring, h, head; lc, lateral condyle; mc, medial condyle; ps, patellar sulcus; tr, trochanter. Note differences in scale bar.

Fig. 4. Scanning electron microscope photomicrographs of the four teeth preserved with NUVF 286. Note the recurved crown, fine crenulations in the enamel, and absence of serrations. 
TABLE 1 --Measurements available for NUVF 286 compared to other Hesperornis femora. All measurements in millimeters (mm)

Hesperornis sp.

Hesperornis regalis

NUVF 286 PU PU YPM 1200* YPM 1206* YPM 1207* YPM 1476* YPM 1477* CMN 10441

1858917193

\begin{tabular}{|c|c|c|c|c|c|c|c|c|c|c|}
\hline & Right & Left & & & Right/Left & Left & Right/Left & Left & Left & Right \\
\hline Length & 94.5 & 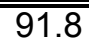 & $\overline{881.9}$ & $\overline{888}$ & $\overline{~ 99 / 99}$ & $\overline{96}$ & $998.5 / 101$ & 105 & 97 & $>75.8$ \\
\hline $\begin{array}{l}\text { Antero-posterior diameter of } \\
\text { head }\end{array}$ & 21.0 & 20.0 & 15.7 & 15.9 & 18.5/18.5 & - & $19 / 18.5$ & - & 19 & - \\
\hline Tranverse diameter of head & 18.5 & 19.5 & 14.5 & 12.1 & - & 18 & - & 19.5 & - & - \\
\hline $\begin{array}{l}\text { Transverse diameter of shaft } \\
\text { near middle }\end{array}$ & 22.0 & - & 23.7 & 19.9 & - & 22 & - & 21 & 20 & 24.4 \\
\hline $\begin{array}{l}\text { Antero-posterior diameter } \\
\text { near middle }\end{array}$ & 18.8 & - & 15.9 & 11.3 & - & - & $18 / 18$ & - & - & 14.1 \\
\hline $\begin{array}{l}\text { Transverse diameter of fibular } \\
\text { articulation }\end{array}$ & - & 14.8 & 15.6 & 14.9 & 14/14.5 & - & $15 / 16$ & 15.5 & 15 & - \\
\hline $\begin{array}{l}\text { Greatest diameter of fibular } \\
\text { articulation }\end{array}$ & - & 21.0 & 22.2 & 20.5 & - & 14 & - & - & - & - \\
\hline $\begin{array}{l}\text { Greatest diameter of inner } \\
\text { condyle }\end{array}$ & 20.5 & - & 19 & 18.6 & $21 / 21$ & 21 & $21 / 21$ & 20 & 20 & 19 \\
\hline $\begin{array}{l}\text { Least diameter of inner } \\
\text { condyle }\end{array}$ & 17.3 & - & 12 & 15 & $14 / 14.5$ & 13 & $13 / 13$ & 18 & 12.5 & - \\
\hline
\end{tabular}

${ }^{*}$ From Marsh (1880) 
FHSM 2069

Right

93.87

18.09

16.85

21.57

19.15

17.75

https://mc06.manuscriptcentral.com/cjes-pubs 


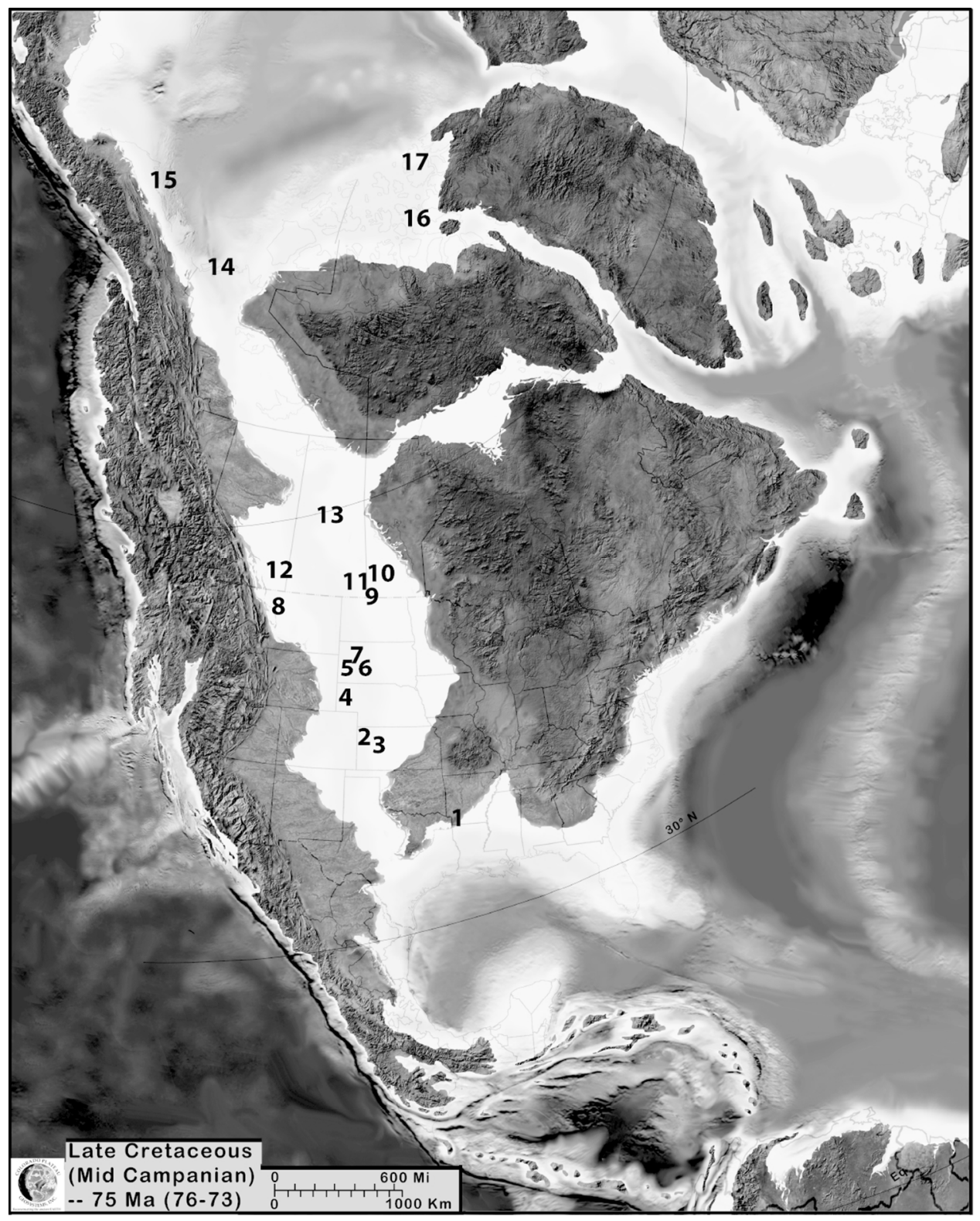

Late Cretaceous North American distribution of specimens attributed to the genus Hesperornis. Map (C)Colorado Plateau Geosystems 2013, used with permission. 1, Hesperornis sp., Ozan Formation (Davis and Harris 1997); 2, Hesperornis regalis, Niobrara Formation (Marsh 1872a, 1880); 3, Hesperornis crassipes, Niobrara Formation (Marsh 1876); 4, Hesperornis sp., Pierre Shale (Martin and Tate 1976); 5, Hesperornis chowi, Pierre Shale (Martin and Lim 2002); 6, Hesperornis bairdi, Pierre Shale (Martin and Lim 2002); 7, Hesperornis regalis, Niobrara Formation (Martin and Varner 1992); 8, Hesperornis altus, Judith River Formation/Clagget Formation (Marsh 1893, Shufeldt 1915, but see Wilson et al. 2011 for discussion of taxonomy); 9, Hesperornis mengeli, Pierre Shale (Martin and Lim 2002); 10, Hesperornis sp., Pembina Formation (Nicholls and Russell 1990); 11, Hesperornis regalis, Hesperornis chowi, Hesperornis macdonaldi, Hesperornis mengeli, Hesperornis lumgairi, Hesperornis cf. rossicus, Pembina Formation (Bardack 1968; Aotsuka \& Sato 2016); 12, Hesperornis cf. regalis, Foremost Formation (Fox 1974); 13, Hesperornis sp.,

Pierre Shale (Tokaryk 1999); 14, vHesperornis regalis, Smoking Hills Formation (Russell 1967); 15, Hesperornis sp., Ignek Formation (Bryant 1983); 16, Hesperornis sp., Kanguk Formation (this paper); 17, 
Hesperornis sp., Kanguk Formation (Hills et al. 1999). $105 \times 132 \mathrm{~mm}(300 \times 300 \mathrm{DPI})$ 


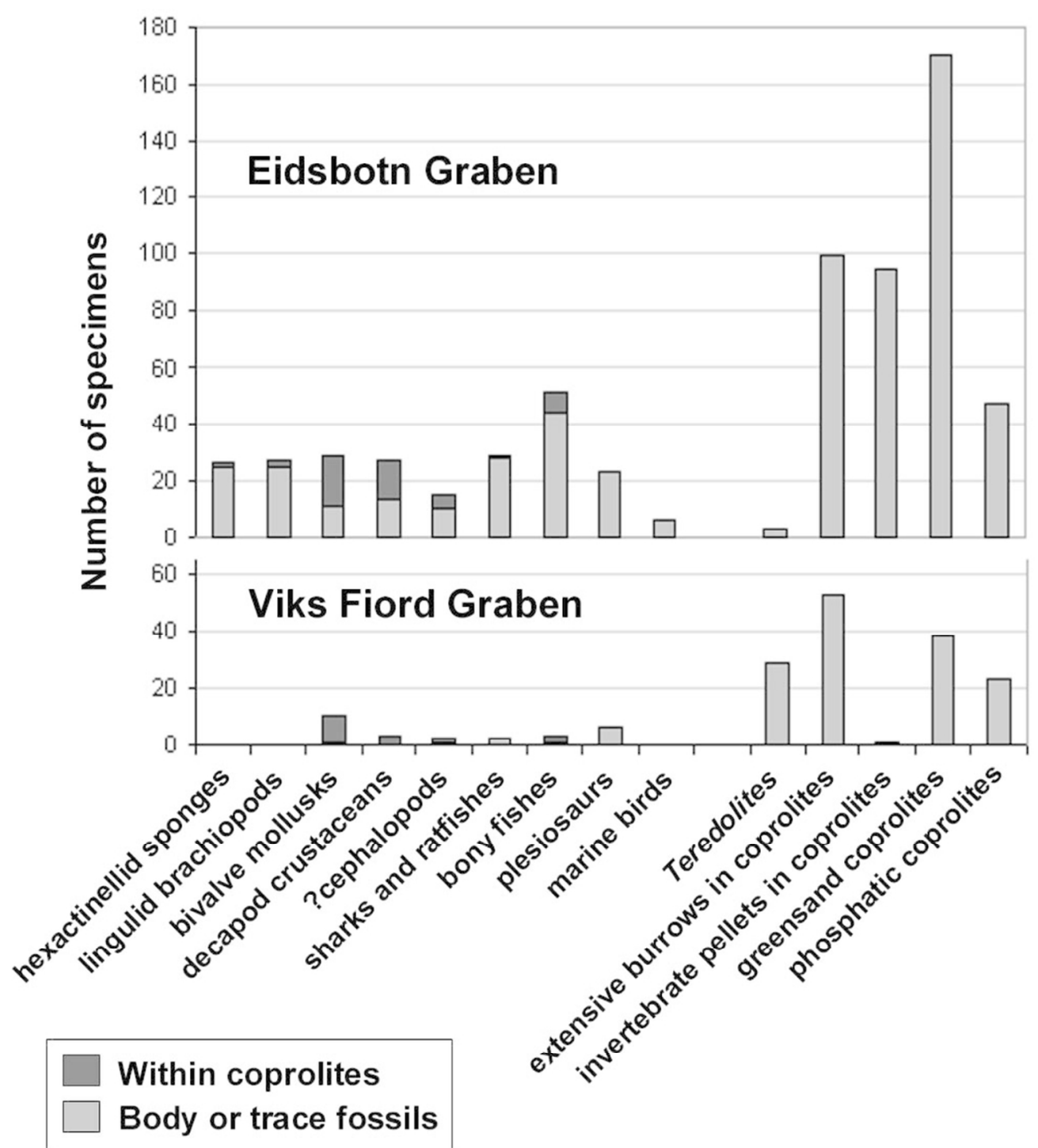

Stacked histograms showing relative number of fossils collected at Eidsbotn and Viks Fiord grabens in the Kanguk Formation on Devon Island. Top (darker) bars indicate numbers of taxa found within coprolites. Note that all body fossils were collected, but only a subset of coprolites were collected.

$100 \times 111 \mathrm{~mm}(300 \times 300 \mathrm{DPI})$ 


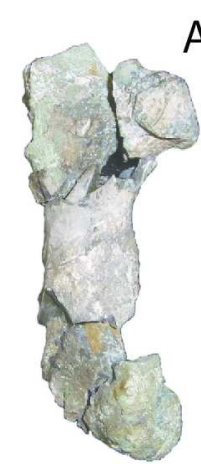

A
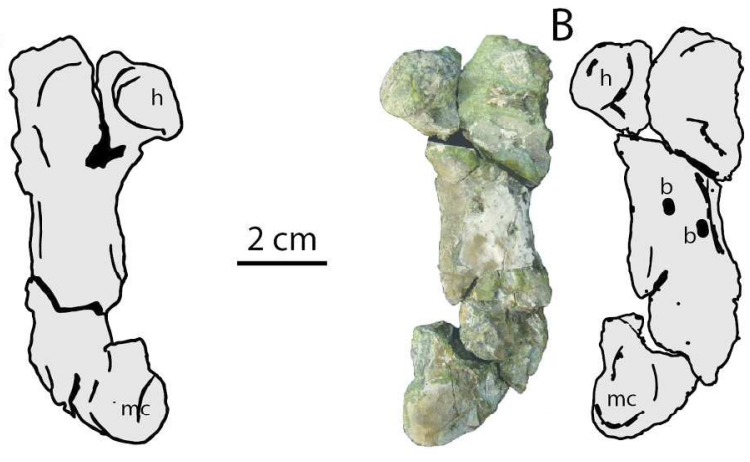

C
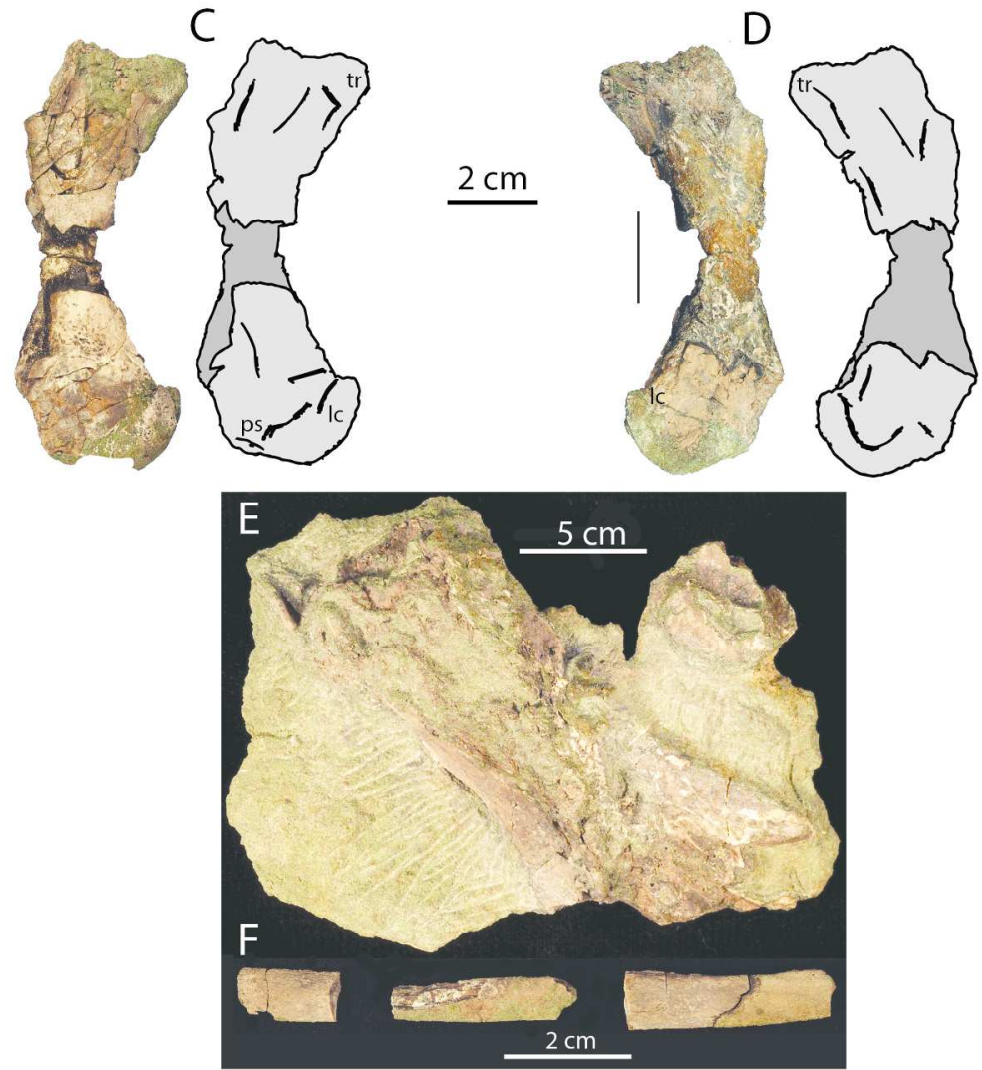

Photographs and line drawings of identifiable bones attributed to NUVF 286. Right femur in cranial (A) and caudal (B) views; left femur in cranial (C) and caudal (D) views; ilia (E) embedded in glauconite matrix; rib fragments (F). Abbreviations: b, boring, h, head; lc, lateral condyle; mc, medial condyle; ps, patellar sulcus; tr, trochanter. Note differences in scale bar.

$$
182 \times 236 \mathrm{~mm}(300 \times 300 \mathrm{DPI})
$$




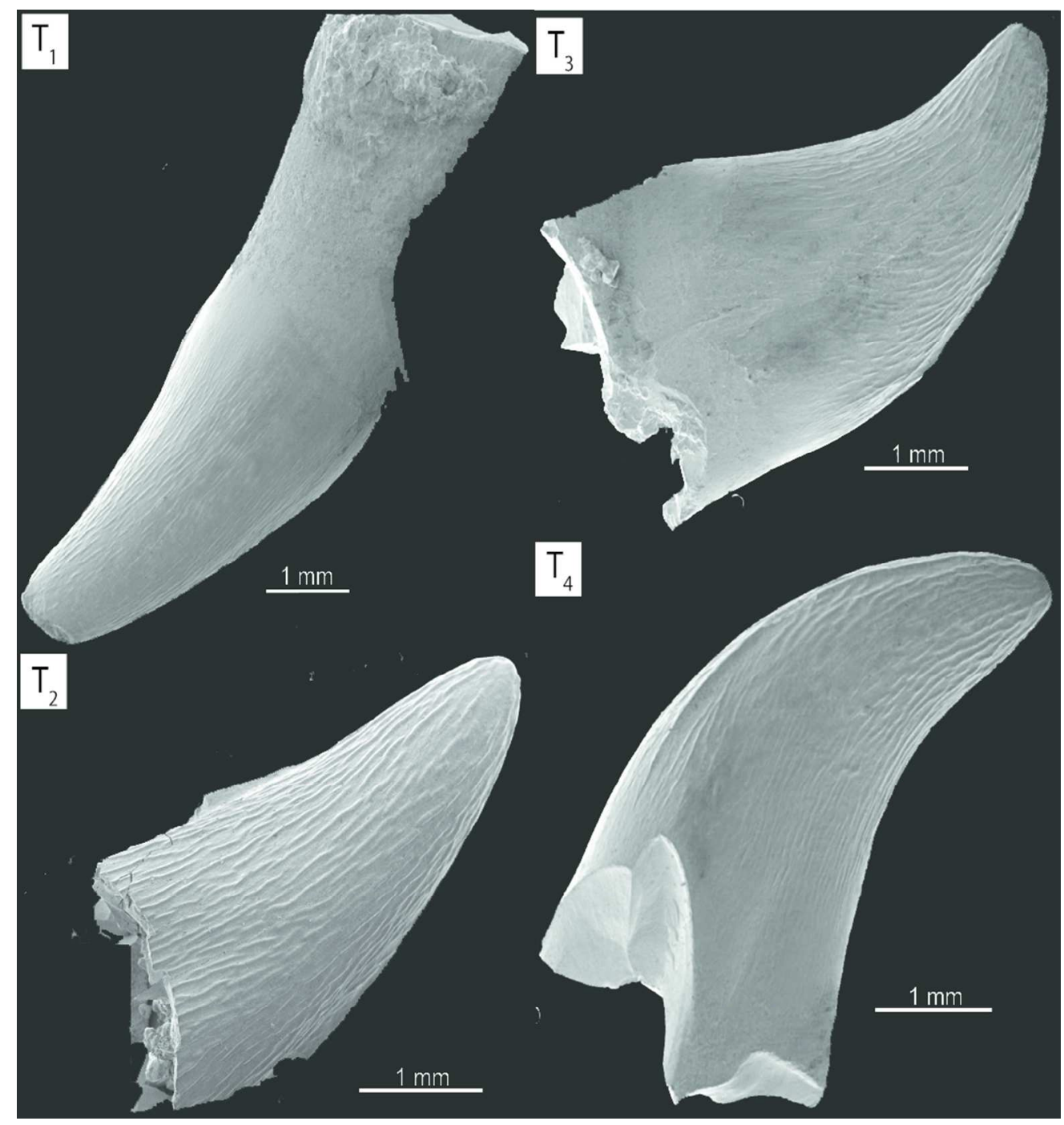

Scanning electron microscope photomicrographs of the four teeth preserved with NUVF 286. Note the recurved crown, fine crenulations in the enamel, and absence of serrations.

$$
90 \times 96 \mathrm{~mm}(300 \times 300 \mathrm{DPI})
$$

